\title{
触 New Disease Reports \\ Pectobacterium carotovorum subsp. brasiliensis causing a soft rot on Styrian oil pumpkin in Austria
}

\author{
R.A. Gottsberger ${ }^{1 *}$ and H. Huss ${ }^{2}$ \\ ${ }^{1}$ Institute for Sustainable Plant Production, Department for Molecular Diagnostics of Plant Diseases, Austrian Agency for \\ Health and Food Safety (AGES), Spargelfeldstrasse 191, 1220 Vienna, Austria; ${ }^{2}$ Institute of Organic Farming and Farm \\ Animal Biodiversity, Agricultural Research \& Education Centre - AREC Raumberg-Gumpenstein, Field Trial Station \\ Lambach/Stadl-Paura, Gmundnerstrasse 9, 4651 Stadl-Paura, Austria
}

*E-mail: richard.gottsberger@ages.at

Received: 29 Jul 2015. Published: 15 Mar 2016. Keywords: bacterial soft rot, Cucurbita, Solanum tuberosum, 16S rDNA

Styrian oil pumpkin (Cucurbita pepo subsp. pepo var. styriaca) is an important crop in the eastern part of Austria, with a cultivated area in 2010 of about 26,000 ha yielding 4 million litres of edible oil worth $€ 60$ million per annum. In September 2014, fruits with soft rot symptoms, i.e. collapsing of the inner pumpkin pulp, resembling that caused by pectolytic Enterobacteriaceae, were sampled in East Styria. The impact of rot on the oil pumpkin fruits in the affected area was more obvious than in preceding years, affecting over $50 \%$ of the crop. Some symptoms differed from the black rot-diseased pumpkins observed previously on the same site attributed to Didymella bryoniae, and associated with Pectobacterium atrosepticum, Pseudomonas viridiflava, Pseudomonas syringae and Xanthomonas cucurbitae (Grube et al., 2011).

Bacteria morphologically similar to Pectobacterium spp. were isolated from the symptomatic pumpkin pulp. DNA from five pure cultures was amplified by PCR using primers targeting the $16 \mathrm{~S}$ rDNA according to Weisburg et al. (1991) and the amplicon sequenced (GenBank Accession No. KU899096). The sequences matched $100 \%$ with P. carotovorum subsp. brasiliensis (Pcb) isolated in China from Brassica rapa (KP187492). The identity of the pumpkin isolates was confirmed by a subspecies-specific PCR targeting the 16S-23S intergenic spacer (Duarte et al., 2004).

Healthy potato plants (from tubers) and oil pumpkin plants cv. Gleisdorfer Ölkürbis (from seeds) were grown in a greenhouse until the four-leaf stage. Suspensions $\left(10^{8} \mathrm{cfu} / \mathrm{ml}\right)$ of a single isolate of $P c b$ (deposited as DSM 102074 in the German Collection of Microorganisms and Cell Cultures, DSMZ) were injected into the stalk of the seedlings using a hypodermic needle, in parallel with a potato strain (DSM 30170) of $P$. c . subsp. carotovorum $(P c c)$ and sterile water as controls. Ten plants were inoculated per isolate. After two weeks, $60 \%$ of the $P c b$-inoculated potato plants showed blackleg symptoms compared to $30 \%$ of the Pcc-inoculated plants. All the pumpkin plants inoculated with $P c b$ showed pronounced symptoms (collapse of entire vines) after three days (Fig. 1), dying shortly afterwards, whereas after two weeks only $10 \%$ of the $P c c$-inoculated plants were symptomatic. Water controls did not show any symptoms. $P c b$ was reisolated from all inoculated symptomatic plants and the subspecies confirmed by PCR. The enhanced aggressiveness of the strain isolated from oil pumpkin was demonstrated by artificial inoculation of both potato and pumpkin plants compared to the Pcc DSMZ strain. However, it should be noted that inoculations were done on young stems rather than fruits.

Although a number of pectolytic bacteria have been described to be responsible for rot diseases in Cucurbitaceae (Balestra, 1999; Sanogo et al., 2011; Yi \& Kim, 1996), to our knowledge, this is the first time Pectobacterium carotovorum subsp. brasiliensis has been isolated from and identified as causing bacterial soft rot in this plant family. This is also the first report of $P c b$ on any crop in Austria; the route of introduction is unknown.

\section{Acknowledgements}

The authors would like to thank Mr. Johann Schaffer for the excellent technical assistance.

\section{References}

Balestra GM, 1999. Gravi attacchi di Erwinia carotovora subsp. carotovora su zucchino in serra nel Lazio. Informatore Fitopatologico 49, 45-48.

Duarte V, Boer SHD, Ward LJ, Oliveira AMRD, 2004. Characterization of atypical Erwinia carotovora strains causing blackleg of potato in Brazil. Journal of Applied Microbiology 96, 535-545.

http://dx.doi.org/10.1111/j.1365-2672.2004.02173.x

Grube M, Fürnkranz M, Zitzenbacher S, Huss H, Berg G, 2011. Emerging multi-pathogen disease caused by Didymella bryoniae and pathogenic bacteria on Styrian oil pumpkin. European Journal of Plant Pathology 131, 539-548. http://dx.doi.org/10.1007/s10658-011-9829-8

Sanogo S, Etarock BF, Clary M, 2011. First report of bacterial wilt caused by Erwinia tracheiphila on pumpkin and watermelon in New Mexico. Plant Disease 95, 1583. http://dx.doi.org/10.1094/PDIS-06-11-0507

Weisburg WG, Barns SM, Pelletier DA, Lane DJ, 1991. 16S ribosomal DNA amplification for phylogenetic study. Journal of Bacteriology 173, 697-703.

Yi Y, Kim R, 1996. Occurrence of bacterial soft rot of melon caused by Erwinia carotovora subsp. carotovora. Korean Journal of Plant Pathology 12, 116-120.

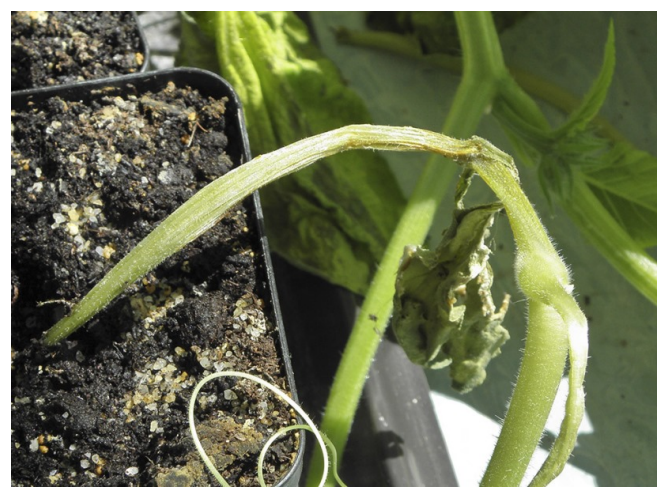

Figure 1

To cite this report: Gottsberger RA, Huss H, 2016. Pectobacterium carotovorum subsp. brasiliensis causing a soft rot on Styrian oil pumpkin in Austria. New Disease Reports 33, 12. http://dx.doi.org/10.5197/j.2044-0588.2016.033.012

(c) 2016 The Authors

This report was published on-line at www.ndrs.org.uk where high quality versions of the figures can be found. 